\title{
Index to Volume 126
}

\section{Compiled by Leslie Cody}

Abies balsamea, 1,234,295

lasiocarpa, 189

Abraham, K.F., 20

Acanthis hornemanni, 113

Acer sp., 15

$$
\text { negundo, } 32,282
$$

rubrum, 1

saccharum, 32

Acinonyx jubatus, 333

Acipenser fulvescens, 204

Aegolius acadicus, 41

Aegolius acadicus) Egg, An Anomalous Northern Saw-whet Owl, 41

Agropyron cristatum, 104,148,221,226

Ailanthus altissima, 32

Alaska, Sea Ice Crossing by Migrating Caribou, Rangifer tarandus, in Northwestern, 217

Alberta, An Extra -

Limital Population of Black-tailed Prairie Dogs, Cynomys ludovicianus, in Central, 46

Alces alces, 189,234

Alces alces Winter Browsing, The Influence of Willow Salix sp. Rose Insect Galls on Moose, 189

Alder, 1

Mountain, 136

Alfalfa, 104,148,158,221,226

Alliaria petiolata, 307

Alnus sp., 1,15 incana ssp. tenuifolia, 136

Amelanchier alnifolia, 136,303 arborea, 282

American Society of Mammalogists Annual Meeting 2013, 265

Anas acuta, 113 platyrhynchos, 41

Anser albifrons, 111

Anthus rubescens, 113

Antrozous sp., 38

Apodemia mormo, 34

Apodemia mormo) Oviposition Behaviour in Canada, First Observations of Mormon Metalmark, 34

Apoemia mormo langei, 36

Arctostaphylos uva-ursi, 298

Arenaria interpres, 113

Ash, Green, 282

Asio flammeus, 41,113

Aspen, 47

Large-tooth, 32

Quaking, 282

Trembling, 295

Aspen (Populus tremuloides) Chronosequence in Central Yukon, Stand-level Attributes of Snowshoe Hare (Lepus americanus) Habitat in a Post-Fire Trembling, 295
Atkinson, J., Review by, 177

Avocettina gilli, 210

infans, 210

Aythya affinis, 16 americana, 16

fuligula, 16

marila, 15,113

valisineria, 16

Aythya marila, Nest Site Characteristics on Grassy Island, New Brunswick, Greater Scaup, 15

Badger, American, 47,95,221,226,234

European, 221

Badgers, Taxidea taxus, in Southwestern Saskatchewan, Observations of Nocturnal Hunting Behaviour of American, 226

Badgers, Taxidea taxus, Use of a Dorsal Radio-Transmitter Implant in American, 221

Baeolophus atricristatus, 143 bicolor, 143

Ballard, Jr. 19472012, Dr. Warren Baxter, 86

Ballard, W.B., 15

Barber-Meyer, S. Severe Maxillary Osteomyelitis in a Gray Wolf (Canis lupus), 238

Barkema, H.W., 288

Barley, 221,226

Bat, 125

Big Brown, 38,117,127

Eastern Red, 117

Hoary, 117

Little Brown, 39

Silver-haired, 118

Tricolored, 118,127

Bat Populations and Cave Microclimate Prior to and at the Outbreak of White-Nose Syndrome in New Brunswick, 125

Bats, Emergency COSEWIC Assessment for Three Species of, 182

Bats (Eptesicus fuscus) in Pennsylvania, Barn Owl (Tyto alba) Predation on Big Brown, 38

Bats (Family Vespertilionidae) at Five Locations in New Hampshire and Massachusetts, Foods of, 117

Bear, American Black, 224,234,321

Grizzly, 224

Bearberry, Common, 298

Beaudoin, A.B. and Y. Beaudoin. Urban White-tailed Jackrabbits (Lepus townsendii) Eat Spike Plants (Cordyline australis) in Winter, 157

Beaudoin, A.B., Reviews by, 77,179,263

Beaudoin, Y., 157

Beaver, American, 283,321

Beetle, 121

Berns, A.M., 160

Betula sp., 1,25,296,320 
occidentalis, 136

papyrifera, 282

Biederman, T., 204

Birch, 1,296,320

Dwarf, 25

Paper, 282

Water, 136

Bishop, C.A., 135,152

Blarina brevicauda, 2,38,93

Bluebird, Mountain, 113

Western, 41

Bluet, Long-leaved, 62

Bobcat, 231

bois de plomb, 86

Bousfield, E.L. and F.R. Cook. A Tribute to Charles Hogg Douglas, 1923-2004, 164

Brachyramphus marmoratus, 6 marmoratus perdix, 6 perdix, 6

Brachyramphus perdix, in North America, Body Condition and Survival of Vagrant Long-billed Murrelets, 6

Brant, Black, 111

Branta bernicla nigricans, 111 hutchinsii, 111

British Columbia, First Specimens of the Marine Eels Venefica ocella and $V$. tentaculata (Nettastomatidae) from, 210

British Columbia, Size of Territories and Home Ranges of Male Western Yellow-breasted Chats (Icteria virens auricollis) in, 152

Britton (1923-2012), Canada's Premier Pteridologist, A Tribute to Donald M., 252

Brodo, I.M. and F.R. Cook. A Tribute to Phillip Merrill Youngman: 1927-2011, 167

Brome, 104,148,221,226

Bromus sp., 104,148,221,226

Brook, R.W., K.F. Abraham, K.R. Middel and R.K. Ross. Abundance and Habitat Selection of Breeding Scoters (Melanitta spp.) in Ontario's Hudson Bay Lowlands, 20

Brunton, D.F. A Tribute to Donald M. Britton (1923-2012), Canada's Premier Pteridologist, 252

Bryum caespiticium, 297

Bubo scandiacus, 113

Buckbrush, 221,226

Buckwheat, Few-flowered, 34

Buffaloberry, 298

Bullsnake, 195

Bunting, Snow, 113

Burg, T.M., 143

Burg, T.M. and R.F. Lauff. An Anomalous Northern Sawwhet Owl (Aegolius acadicus) Egg, 41

Buteo lagopus, 113

Butterfly, 36

Calamogrostis sp., 15 canadensis, 1 purpurascens, 298

Calathus sp., 121

Calcarius lapponicus, 113

Calidris bairdii, 111 fuscicollis, 113 himantopus, 111

melanotos, 113

pusilla, 113

Callaghan, C., Review by, 83

Camptorhynchus labradorius, 329

Canada, A Partial Albino Hatchling Northern Ring-necked Snake, Diadophis punctatus edwardsii, from Big Tancook Island, Mahone Bay, Lunenburg County, Nova Scotia, 336

Canada, A Significant Range Extension for the Eastern Ribbonsnake, Thamnophis sauritus, in Nova Scotia, 231

Canada, A Specimen of the High Arctic Subspecies of Atlantic Puffin, Fratercula arctica naumanni, in, 50

Canada, First Observations of Mormon Metalmark (Apodemia mormo) Oviposition Behaviour in, 34

Canada, First Record of Parasites from Cougars (Puma concolor) in Manitoba, 324

Canada, Genetic Evidence Supports Boreal Chickadee (Poecile hudsonicus) $\times$ Black-capped Chickadee (Poecile atricapillus) Hybridization in Atlantic, 143

Canada, Population Structure of Harvested Red Foxes (Vulpes vulpes) and Coyotes (Canis latrans) on Prince Edward Island, 288

Canada's Premier Pteridologist, A Tribute to Donald M. Britton (1923-2012), 252

Canadian Field-Naturalist 119(3): 359, Erratum The, 265

Canadian Field-Naturalist 126(3): 245, Erratum The, 353

Canadian Field-Naturalist Instructions for Authors, The, 186,278

Canadian Herpetologist (TCH) 2(1), Spring 2012, The, 182

Canadian Herpetologist (TCH) 2(2), Fall 2012, The, 353

Canis sp., 237

familiaris, 321

latrans, 47,95,288,321,324

lupus, 238,324

lupus lycaon, 235

lupus rufus, 143

Canis latrans) on Prince Edward Island, Canada, Population Structure of Harvested Red Foxes (Vulpes vulpes) and Coyotes, 288

Canis lupus), Severe Maxillary Osteomyelitis in a Gray Wolf, 238

Canvasback, 16

Capercaillie, 331

Capra pyrenaica, 192

Carduelis hornemanni, 113

Carex sp., 15,25

macloviana, 62

soperi, 62

Caribou, 217

Caribou, Rangifer tarandus, in Northwestern Alaska, Sea Ice Crossing by Migrating, 217

Carter, H.R., 6

Carter, R.A., 320

Carya sp., 28

Castanea sp., 255

Castor canadensis, 283,321

Caswell, G., 336

Cat, 47

Domestic, 321

Feral, 286

Catling, P.M., Review by, 71 
Ceanothus sp., 221,226

Cedar, Eastern White, 160

Celtis occidentalis, 32 tenuifolia, 62

tenuifolia var. soperi, 62

Ceratodon purpureus, 297

Cervus elaphus, 46,320

Chamaedaphne calyculata, 24

Chamerion angustifolium, 298

Charadrius semipalmatus, 113

Chat, Eastern Yellow-breasted, 135

Western Yellow-breasted, 135,152

Yellow-breasted, 135,152

Chat (Icteria virens auricollis) at the Northern Edge of its Range, Site Fidelity and Annual Survival of the Western Yellow-breasted, 135

Chats (Icteria virens auricollis) in British Columbia, Size of Territories and Home Ranges of Male Western Yellowbreasted, 152

Cheetah, 333

Chen caerulescens, 113

Chenopodium album, 32

Cherry, Black, 32

Chickadee, Black-capped, 143

Boreal, 143

Carolina, 143

Mountain, 143

Chickadee (Poecile atricapillus) Hybridization in Atlantic Canada, Genetic Evidence Supports Boreal Chickadee (Poecile hudsonicus) $\times$ Black-capped, 143

Chickadee (Poecile hudsonicus) $\times$ Black-capped Chickadee (Poecile atricapillus) Hybridization in Atlantic Canada, Genetic Evidence Supports Boreal, 143

Chionoecetes tanneri, 210

Chokecherry, 282

Chrysomelidae sp., 121

Clangula hyemalis, 113

Clark, H.O. Jr., Review by, 68

Coad, B.W., Review by, 173

Cochran, P.A., M.A. Ross, T.S. Walker, and T. Biederman. Early Spawning by the American Brook Lamprey (Lethenteron appendix) in Southeastern Minnesota, 204

Colaptes auratus, 41,143

Coluber constrictor flaviventris, 195 taeniatus, 199

Cook, F.R., 164,167

Cook, F.R., Reviews by, 340,341,342,344,345

Cordyline sp., 157 australis, 157

Cordyline australis) in Winter, Urban White-tailed Jackrabbits (Lepus townsendii) Eat Spike Plants, 157

Cornus sp., 15

racemosa, 282

stolonifera, 136

Corvus corax, 113,235

corone cornix, 41

corone corone, 41

Corylus cornuta, 234,303

Corynoptera phili, 170

Cottonwood, Black, 136

Eastern, 32,282
Cottus cognatus, 207

Cougar, 236,320,324,333

Cougar (Puma concolor) Kittens with Live Prey: Implications for Learning and Survival, Observations of Wild, 333

Cougars (Puma concolor) in Manitoba, Canada, First Record of Parasites from, 324

Cougars, Puma concolor, in Ontario: Additional Evidence, 320

Coyote, 47,95,288,321,324

Coyotes (Canis latrans) on Prince Edward Island, Canada, Population Structure of Harvested Red Foxes (Vulpes vulpes) and, 288

Crab, Tanner, 210

Cranberry, Bog, 298 Low-bush, 303

Crane, Sandhill, 111

Crataegus sp., 282

Crimmins, S.M., 28

Crins, W.J., Review by, 178

Crotalus oreganus, 199 viridis, 195

Crow, Carrion, 41 Hooded, 41

Cucumber, Burr, 32

Curlews, Eskimo, 329

Cyema atrum, 210

Cygnus columbianus, 113

Cynomys sp., 15,46 ludovicianus, 46

Cynomys ludovicianus, in Central Alberta, An Extra-Limital Population of Black-tailed Prairie Dogs, 46

Cystopteris sp., 255 fragilis, 253

Dare, O.K. and W.G. Watkins. First Record of Parasites from Cougars (Puma concolor) in Manitoba, Canada, 324

de Bie, F., 288

Deer, 194,237,242

Mule, 320,326,334

White-tailed, 47,160,237,242,320,326

Deer Herbivory and Drought on Population Growth of Goodyera pubescens (Orchidaceae) in Southwestern Quebec, The Impact of, 242

Delichon urbicum, 143

Dendroica occidentalis, 143 townsendi, 143

Dezhi, L. and Q. Aili, Review by, 347

Diadophis punctatus edwardsii, 336

Diadophis punctatus edwardsii, from Big Tancook Island, Mahone Bay, Lunenburg County, Nova Scotia, Canada, A Partial Albino Hatchling Northern Ring-necked Snake, 336

Dicranum sp., 329 scoparium, 329

Dilworth, T.G., 15

Dirca decipiens, 86 mexicana, 86 occidentalis, 86 palustris), 86

Dirca palustris), On the Discovery of Eastern, Leatherwood, 86

Dog, Domestic, 321 
Dogwood, Grey, 282

Red-osier, 136

Dorosoma cepedianum, 10

Douglas-fir, 189

Douglas, 1923-2004, Tribute to Charles Hogg, 164

Dracaena indivisa, 157

Drake, C., 336

Dryopteris sp., 253 algonquinensis, 253

filix-mas spp. brittonii, 255

fragrans, 253

Duck, Labrador, 329

Long-tailed, 113

Tufted, 16

Dunn, E.H., 59

Echinococcus sp., 288

Editor's Report for Volume 125 (2011), 184

Edwards, 1924-2011, Yorke, 353

Eel, Marine, 210

Eels Venefica ocella and $V$. tentaculata (Nettastomatidae) from British Columbia, First Specimens of the Marine, 210

Egret, Reddish, 328

Egret (Egretta rufescens) in Nova Scotia During the 19th Century and its Association with the McCulloch Collection of Birds, Evidence for the Collection of a Reddish, 328

Egretta rufescens, 328

Egretta rufescens) in Nova Scotia During the 19th Century and its Association with the McCulloch Collection of Birds, Evidence for the Collection of a Reddish Egret, 328

Eider, Common, 113

King, 111

Elaeagnus angustifolia, 307

Elateridae sp., 121

Elbroch, L.M. and H. Quigley. Observations of Wild Cougar (Puma concolor) Kittens with Live Prey: Implications for Learning and Survival, 333

Elk, North American, 46,320

Elm, 47

American, 282

Elymus trachycaulus, 104,148,221,226

Emydoidea blandingii, 89,232

Emydoidea blandingii, in Barren Meadow and Keddy Brooks, Nova Scotia, Ecology of a Recently Discovered Population Segment of Blanding's Turtles, 89

Eptesicus fuscus, 38,117,127

Eptesicus fuscus) in Pennsylvania, Barn Owl (Tyto alba) Predation on Big Brown Bats, 38

Erbilgin, N., 34

Eremophila alpestris, 113

Erethizon dorsatus, 326

Ericameria nauseosa, 34

Eriogonum pauciflorum, 34

Ermine, 228

Falco columbarius, 113 peregrinus, 113

Falcon, Peregrine, 113

Fecske, D.M., 281
Felis catus, 47,286,321

Fern, Bracken, 235

Britton's Male, 255

Britton's Oak, 255

Fragile, 253

Fir, Balsam, 1,234,295

Subalpine, 189

Fireweed, 298

Fisher, 234,281,321

Fisher, Martes pennanti, In situ Caching of a Large Mammal Carcass by a, 234

Fishers, Martes pennanti, in North Dakota, A Direct Comparison of Enclosed Track Plates and Remote Cameras in Detecting, 281

Flicker, Northern, 41,143

Fly, 170

Forbes, G., 1

Forbes, G.J., 125

Fortier, J.L., 320

Fortney, A.N., R.G. Poulin, J.A. Martino, D.L. Parker and C.M. Somers. Proximity to Hibernacula and Road Type Influence Potential Road Mortality of Snakes in Southwestern Saskatchewan, 194

Fox, Arctic, 114

Kit, 224

Red, 95,235,231,288

Foxes (Vulpes vulpes) and Coyotes (Canis latrans) on Prince Edward Island, Canada, Population Structure of Harvested Red, 288

Fratercula arctica arctica, 50

arctica grabae, 50

arctica naumanni, 50

Fratercula arctica naumanni, in Canada, A Specimen of the High Arctic Subspecies of Atlantic Puffin, 50

Fraxinus sp., 15 pennsylvanica, 282

Frederick, C.F., 160

Gallagher, E., 28

Gartersnake, Plains, 195 Wandering, 195

Gaston, A.J. and J.F. Provencher. A Specimen of the High Arctic Subspecies of Atlantic Puffin, Fratercula arctica naumanni, in Canada, 50

Gavia adamsii, 113

pacifica, 113

stellata, 113

Geomyces destructans, 127

Geomys bursarius, 226

Gilhen, J., A. Jones, J. McNeil, and A.W. Tanner. A Significant Range Extension for the Eastern Ribbonsnake, Thamnophis sauritus, in Nova Scotia, Canada, 231

Gilhen, J., G. Caswell, C. Drake, M. MacDonald, and H. McKinnon-Ramshaw. A Partial Albino Hatchling Northern Ring-necked Snake, Diadophis punctatus edwardsii, from Big Tancook Island, Mahone Bay, Lunenburg County, Nova Scotia, Canada, 336

Glaucidium gnoma, 43

Global Wildlife Resources — Wildlife Handling Job Board, 182

Gloeophyllum trabeum, 161

Glycine javanica, 31 
$\max , 33$

Goat, Iberian Wild, 192

Golden-Plover, American, 111

Goodyera pubescens, 242

Goodyera pubescens (Orchidaceae) in Southwestern Quebec, The Impact of Deer Herbivory and Drought on Population Growth of, 242

Goose, Cackling, 111 Greater White-fronted, 111

Snow, 113

Gooseberry, Missouri, 282

Gopher, Northern Pocket, 96

Plains Pocket, 226

Pocket, 167

Grape, Riverbank, 32

Gray, D.R. and S.E. Gray. A Tribute to Stewart Dixon MacDonald, 1927-2010, 245

Gray, S.E., 245

Grouse, Black, 331

Red, 292,331

Grus canadensis, 111

Gull, American Herring, 113

Glaucous, 113

Great Black-backed, 15

Ring-billed, 15

Sabine's, 113

Thayer's, 111

Gulo gulo, 234

Gymnocarpium sp., 255

brittonianum, 255

Haber, E. A Tribute to James Herbert Soper, 1916-2012, 61

Hackberry, 32

Dwarf, 62

Hamilton, D.A., 28

Hanke, G.F. and S.M. Roias. First Specimens of the Marine Eels Venefica ocella and $V$. tentaculata (Nettastomatidae) from British Columbia, 210

Hare, Snowshoe, 237,295,303

Hare (Lepus americanus) Habitat in a Post-Fire Trembling Aspen (Populus tremuloides) Chronosequence in Central Yukon, Stand-level Attributes of Snowshoe, 295

Hawk, Rough-legged, 113

Hawthorn, 282

Hazelnut, Beaked, 234,303

Hellebore, California False, 55 Green False, 55

Helleiner, F., Review by, 69

Henderson, J. and G. Forbes. Occurrence of the Maritime Shrew (Sorex maritimensis) in Black Spruce (Picea mariana) Forest Stands in Southeastern New Brunswick, 1

Herman, T.B., 89

Heterodon nasicus, 195

Hickory, 28

Hirundo rustica, 143

Histiobranchus bathybius, 210

Holroyd, G.L., 46

Holt, J., 117

Homo sapiens, 321
Hordeum vulgare, 221,226

Hormathophylla spinosa, 192

Houston, C.S., Reviews by, 174,346

Houstonia longifolia, 62 longifolia var. soperi, 62

Huettmann, F., Review by, 349

Human, 321

Hüner, E.A. and J.F.B. Peter. In situ Caching of a Large Mammal Carcass by a Fisher, Martes pennanti, 234

Hussell, D.J.T., J.A.T. Hussell, and E.H. Dunn. New Avian Breeding Records for Iqaluit, Nunavut, 59

Hussell, J.A.T., 59

Hydrilla verticillata, 307

Hydrilla, 307

Hylocomium splendens, 299

Hypnum imponens, 329

Ichthyomyzon unicuspis, 207

Icteria virens, 135,152

virens auricollis, 135,152

virens virens, 135

Icteria virens auricollis) at the Northern Edge of its Range, Site Fidelity and Annual Survival of the Western Yellow-breasted Chat, 135

Icteria virens auricollis) in British Columbia, Size of Territories and Home Ranges of Male Western Yellowbreasted Chats, 152

Isoetes $\mathrm{sp} ., 253$

brittonii, 255

dodgei, 253

virginica, 255

Iudica, C.A., 38

Jackrabbit, White-tailed, 157

Jackrabbits (Lepus townsendii) Eat Spike Plants (Cordyline australis) in Winter, Urban White-tailed, 157

Jaeger, Long-tailed, 113

Parasitic, 113

Pomarine, 113

Janelle, J., 34

John, R., Reviews by, 70,71,172,176,260,261

Johnston, D., 288

Joly, K. Sea Ice Crossing by Migrating Caribou, Rangifer tarandus, in Northwestern Alaska, 217

Jones, A., 231

Junco hyemalis, 60

Junco, Dark-eyed, 60

Jung, T.S., 295

Kehoe, F.P., 15

Kenn, I.S., 320

Khalafalla, S.M. and C.A. Iudica. Barn Owl (Tyto alba) Predation on Big Brown Bats (Eptesicus fuscus) in Pennsylvania, 38

Kingsnake, Prairie, 201

Kudzu, 307

Lagopus lagopus, 113

lagopus scotica, 331

lagopyus scoticus, 292 
muta, 113

Lait, L.A., R.F. Lauff, and T.M. Burg. Genetic Evidence Supports Boreal Chickadee (Poecile hudsonicus) $\times$ Blackcapped Chickadee (Poecile atricapillus) Hybridization in Atlantic Canada, 143

Lamb's-quarters, 32

Lampetra appendix, 204

Lamprey, American Brook, 204

Sea, 206

Silver, 207

Lamprey (Lethenteron appendix) in Southeastern Minnesota, Early Spawning by the American Brook, 204

Lampropeltis calligaster calligaster, 201

Larix laricina, 1,24

Lark, Horned, 113

Larson, B.M.H., 31

Larus argentatus smithsonianus, 113 delawarensis, 15

hyperboreus, 113

marinus, 15

thayeri, 111

Lasionycteris noctivagans, 118

Lasiurus borealis, 117 cinereus, 117

Lauff, R., Review by, 262

Lauff, R.F., 41,143

Leatherleaf, 24

Leatherwood, Eastern, 86 Mexican, 86

Western, 86

Leatherwood (Dirca palustris), On the Discovery of Eastern, 86

Lefebvre, J., S.W. Mockford, and T.B. Herman. Ecology of a Recently Discovered Population Segment of Blanding's Turtles, Emydoidea blandingii, in Barren Meadow and Keddy Brooks, Nova Scotia, 89

Lemming, 114

Lepus americanus, 237,295 townsendii, 157

Lepus americanus) Habitat in a Post-Fire Trembling Aspen (Populus tremuloides) Chronosequence in Central Yukon, Stand-level Attributes of Snowshoe Hare, 295

Lepus townsendii) Eat Spike Plants (Cordyline australis) in Winter, Urban White-tailed Jackrabbits, 157

Lespedeza cuneata, 307

Lespedeza, Sericea, 307

Lethenteron appendix, 204

Lethenteron appendix) in Southeastern Minnesota, Early Spawning by the American Brook Lamprey, 204

Letter to the Editor, 183

Lichen, Dog Tongue, 298

Lindgren, C.J. and D. Walker. Predicting the Spread of Purple Loosestrife (Lythrum salicaria) in the Prairies, 306

Linnaea borealis, 299

Lion, 224

Locust, Black, 32

Lok, C.M. and J.A.J. Vink. Trends and Fluctuations in Bird Populations on the Tundra at Cambridge Bay, Nunavut, 111

Longspur, Lapland, 113
Lontra canadensis, 28

Lontra canadensis, in Southern Missouri, Implantation and Parturition Dates of North American River Otters, 28

Loon, Pacific, 113

Red-throated, 113

Yellow-billed, 113

Loosestrife, Purple, 306

Loosestrife (Lythrum salicaria) in the Prairies, Predicting the Spread of Purple, 306

Lophodytes cucullatus, 41

Lophura imperialis, 143

Loughry, S.C., M.D. Triska, D.M. Fecske, and T.L. Serfass. A Direct Comparison of Enclosed Track Plates and Remote Cameras in Detecting Fishers, Martes pennanti, in North Dakota, 281

Lupine, Arctic, 298

Lupinus arcticus, 299

Lynx canadensis, 295,321 rufus, 321

Lynx, Canada, 295,321

Lythrum salicaria, 15,306

Lythrum salicaria) in the Prairies, Predicting the Spread of Purple Loosestrife, 306

MacDonald, M., 336

MacDonald, 1927-2010, A Tribute to Stewart Dixon, 245

MacKenzie, K., 103

MacKenzie, N., 103,221,226

Mallard, 41

Malloch, D., 125

Mallory, F.F., R.A. Carter, J.L. Fortier, I.S. Kenn, L. Weis, and B.N. White. Cougars, Puma concolor, in Ontario: Additional Evidence, 320

Manitoba, Canada, First Record of Parasites from Cougars (Puma concolor) in, 324

Maple, Manitoba, 32,282

Red, 1

Sugar, 32

Marmot, Bobak, 56

Golden, 56

Hoary, 56

Long-tailed, 56

Olympic, 56

Steppe, 56

Vancouver Island, 55

Yellow-bellied, 55

Marmota bobak, 56

caligulata, 56

caudate, 56

flaviventris, 55

monax, 56

olympus, 56

vancouverensis, 55

Marmota vancouverensis) Consume Plants Containing Toxic Secondary Compounds, Vancouver Island Marmots, 55

Marmots (Marmota vancouverensis) Consume Plants Containing Toxic Secondary Compounds, Vancouver Island, 55

Marten, American, 234

European Pine, 234 
Martes americana, 234

martes, 234

pennanti, 234,281,321

Martes pennanti, in North Dakota, A Direct Comparison of Enclosed Track Plates and Remote Cameras in Detecting Fishers, 281

Martes pennanti, In situ Caching of a Large Mammal Carcass by a Fisher, 234

Martin, Common House, 143 Northern House, 143

Martino, J.A., 194

Massachusetts, Foods of Bats (Family Vespertilionidae) at Five Locations in New Hampshire and, 117

McAlpine, D.F., 125

McKibbon, R. and C.A. Bishop. Site Fidelity and Annual Survival of the Western Yellow-breasted Chat (Icteria virens auricollis) at the Northern Edge of its Range, 135

McKibbin, R. and C.A. Bishop. Size of Territories and Home Ranges of Male Western Yellow-breasted Chats (Icteria virens auricollis) in British Columbia, 152

McKinnon-Ramshaw, H., 336

McNeil, J., 231

McRoberts, J.T, N.T. Quintana, W.A. Smith, W.B. Ballard, F.P. Kehoe, and T.G. Dilworth. Greater Scaup, Aythya marila, Nest Site Characteristics on Grassy Island, New Brunswick, 15

Meadowlark, Eastern, 143 Western, 143

Medicago sp., 104,148,221,226 sativa, 158

Meerkat, 333

Megachile sculpturalis, 33

Melanitta sp., 20 americana, 20

fusca, 20 perspicillata, 20

Melanitta spp.) in Ontario's Hudson Bay Lowlands, Abundance and Habitat Selection of Breeding Scoters, 20

Meles meles, 221

Mephitis mephitis, 150,283

Merganser, Hooded, 41 Red-breasted, 113

Mergus serrator, 113

Merlin, 113

Metalmark, Lange's, 36 Mormon, 34

Metalmark (Apodemia mormo) Oviposition Behaviour in Canada, First Observations of Mormon, 34

Microtus pennsylvanicus, 38

Middel, K.R., 20

Mills, E.L. Evidence for the Collection of a Reddish Egret (Egretta rufescens) in Nova Scotia During the 19th Century and its Association with the McCulloch Collection of Birds, 328

Mills, E.L., Review by, 81

Minutes of the $133^{\text {rd }}$ Annual Business Meeting of The Ottawa Field-Naturalists' Club January 10, 2012, 266

Minnesota, Early Spawning by the American Brook Lamprey (Lethenteron appendix) in Southeastern, 204

Missouri, Implantation and Parturition Dates of North American River Otters, Lontra canadensis, in Southern, 28
Mockford, S.W., 89

Moose, 189,234

Moose Alces alces Winter Browsing, The Influence of Willow Salix sp. Rose Insect Galls on, 189

Moosewood, 86

Moosman, P.R. Jr., 117

Morus alba, 32

Moss, 329

Bryum, 297

Fire, 297

Pioneer, 298

Stairstep, 299

Moth, 121

Mottiar, Y. On the Discovery of Eastern Leatherwood (Dirca palustris), 86

Mouse, Deer, 2,321

Northern Grasshopper, 96

Olive-backed Pocket, 96

Western Harvest, 95

Mouse, Reithrodontomys megalotis, An Addition to the Mammalian Fauna of Saskatchewan: The Western Harvest, 95

Mulberry, White, 32

Murre, Thick-billed, 50

Murrelet, Long-billed, 6 Marbled, 6

Murrelets, Brachyramphus perdix, in North America, Body Condition and Survival of Vagrant Long-billed, 6

Mustard, Garlic, 307 Yellow, 226

Mustela erminea, 228 eversmanni, 168 frenata, $95,228,234$

Myodes gapperi, 2

Myotis sp., 38,121,127 leibii, 118

lucifugus, 39, 117,127

septentrionalis, 118,127

sodalis, 118

Myotis, Eastern Small-footed, 118

Indiana, 118

Little Brown, 117

Northern, 117

Nemichthys avocetta, 210

larseni, 210

scolopaceus, 210

Neospora caninum, 288

Neotoma cinerea, 96

New Brunswick, Bat Populations and Cave Microclimate Prior to and at the Outbreak of White-Nose Syndrome in, 125

New Brunswick, Greater Scaup, Aythya marila, Nest Site Characteristics on Grassy Island, 15

New Brunswick, Occurrence of the Maritime Shrew (Sorex maritimensis) in Black Spruce (Picea mariana) Forest Stands in Southeastern, 1

New Hampshire and Massachusetts, Foods of Bats (Family Vespertilionidae) at Five Locations in, 117

North America, Body Condition and Survival of Vagrant Long-billed Murrelets, Brachyramphus perdix, in, 6 
North Dakota, A Direct Comparison of Enclosed Track Plates and Remote Cameras in Detecting Fishers, Martes pennanti, in North Dakota, 281

Northeast Natural History Conference 2013, 265

Notropis atherinoides, 10

Nova Scotia, Canada, A Partial Albino Hatchling Northern Ring-necked Snake, Diadophis punctatus edwardsii, from Big Tancook Island, Mahone Bay, Lunenburg County, 336

Nova Scotia, Canada, A Significant Range Extension for the Eastern Ribbonsnake, Thamnophis sauritus, in, 231

Nova Scotia During the $19^{\text {th }}$ Century and its Association with the McCulloch Collection of Birds, Evidence for the Collection of a Reddish Egret (Egretta rufescens) in, 328

Nova Scotia, Ecology of a Recently Discovered Population Segment of Blanding's Turtles, Emydoidea blandingii, in Barren Meadow and Keddy Brooks, 89

Numenius borealis, 329

Nunavut, New Avian Breeding Records for Iqaluit, 59

Nunavut, Trends and Fluctuations in Bird Populations on the Tundra at Cambridge Bay, 111

O’Neill, J., Reviews by, 77,80

Oahandley, R.M., 288

Oak, 28

Burr, 282

Northern Red, 160

Red, 32

Odocoileus sp., 194,237

hemionus, 320,326,334

virginianus, 47,160,237,242,320,326

Oenanthe oenanthe, 59

Oleria onega, 36

Olive, Russian, 307

Ontario: Additional Evidence, Cougars, Puma concolor, in, 320

Ontario, Kudzu Vine, Pueraria montana, Adventive in Southern, 31

Ontario's Hudson Bay Lowlands, Abundance and Habitat Selection of Breeding Scoters (Melanitta spp.) in, 20

Onychomys leucogaster, 96

Ottawa Field-Naturalists' Club Awards for 2011, Presented April 2012, The, 254

Otter, North American River, 28

Otters, Lontra canadensis, in Southern Missouri, Implantation and Parturition Dates of North American River, 28

Owl, Barn, 38

Northern Pygmy, 43

Northern Saw-whet, 41

Short-eared, 41,113

Snowy, 113

Owl (Aegolius acadicus) Egg, An Anomalous Northern Sawwhet, 41

Owl (Tyto alba) Predation on Big Brown Bats (Eptesicus fuscus) in Pennsylvania, Barn, 38

Panthera leo, 224

Parker, D.L., 194

Passer domesticus, 38

Passerculus sandwichensis, 59,113
Pellaea sp., 253

Peltigera aphthosa, 299 malacea, 299

Pennsylvania, Barn Owl (Tyto alba) Predation on Big Brown Bats (Eptesicus fuscus) in, 38

Perimyotis subflavus, 118,126

Perognathus fasciatus, 96

Peromyscus maniculatus, 2,321

Peter, J.F.B., 234

Petromyzon marinus, 206

Phakopsora pachyrizi, 33

Phalaris sp., 15

Phalarope, Red, 111 Red-necked, 111

Phalaropus fulicarius, 111 lobatus, 111

Pheasant, Imperial, 143

Picea sp., 47,296 albertiana ssp. albertiana, 296 glauca, 234 mariana, 1,24,295

Picea mariana) Forest Stands in Southeastern New Brunswick, Occurrence of the Maritime Shrew (Sorex maritimensis) in Black Spruce, 1

Pine, 28

Eastern White, 1,234

Lodgepole, 296

Pintail, Northern, 113

Pinus sp., 28 contorta var. latifolia, 296 strobus, 1,234

Pipit, American, 113

Pituophis catenifer, 199 catenifer sayi, 195

Plant, Cane, 157

Dracaena, 157

Spike, 157

Plants (Cordyline australis) in Winter, Urban White-tailed Jackrabbits (Lepus townsendii) Eat Spike, 157

Plectrophenax nivalis, 113

Pleurozium schreberi, 330

Plover, Black-bellied, 111 Semipalmated, 113

Pluvialis dominica, 111 squatarola, 111

Poecile atricapillus, 143 carolinensis, 143 gambeli, 143 hudsonicus, 143

Poecile atricapillus) Hybridization in Atlantic Canada, Genetic Evidence Supports Boreal Chickadee (Poecile hudsonicus) $\times$ Black-capped Chickadee, 143

Poecile hudsonicus) $\times$ Black-capped Chickadee (Poecile atricapillus) Hybridization in Atlantic Canada, Genetic Evidence Supports Boreal Chickadee, 143

Polecat, Beringian, 168

Polypodium sp., 253

Polystichum sp., 253

Poplar, 320

Balsam, 282

Populus sp., 47,320

basamifera, 282 
deltoides, 32,282

grandidentata, 32

tremuloides, 282,295

trichocarpa, 136

Populus tremuloides) Chronosequence in Central Yukon, Stand-level Attributes of Snowshoe Hare (Lepus americanus) Habitat in a Post-Fire Trembling Aspen, 295

Porcupine, North American, 326

Poulin, R.G., 194

Prairie Dog, 46 Black-tailed, 46

Prairie Dogs, Cynomys ludovicianus, in Central Alberta, An Extra-Limital Population of Black-tailed, 46

Prince Edward Island, Canada, Population Structure of Harvested Red Foxes (Vulpes vulpes) and Coyotes (Canis latrans) on, 288

Procyon lotor, 93,286

Proulx, B.P., 95

Proulx, G. and B.P. Proulx. An Addition to the Mammalian Fauna of Saskatchewan: The Western Harvest Mouse, Reithrodontomys megalotis, 95

Proulx, G. and N. MacKenzie. Observations of Nocturnal Hunting Behaviour of American Badgers, Taxidea taxus, in Southwestern Saskatchewan, 226

Proulx, G. and N. MacKenzie. Use of a Dorsal RadioTransmitter Implant in American Badgers, Taxidea taxus, 221

Proulx, G. High Spring Mortality of Adult Richardson's Ground Squirrels, Urocitellus richardsonii, Associated with a Severe Rainstorm in Southwestern Saskatchewan, 148

Proulx, G., K. MacKenzie, and N. MacKenzie. Distribution and Relative Abundance of Richardson's Ground Squirrels, Urocitellus richardsonii, According to Soil Zones and Vegetation Height in Saskatchewan During a Drought Period, 103

Provencher, J.F., 50

Prunus serotina, 32 virginiana, 282

Pruss, S., 34

Pseudotsuga menziesii, 189

Ptarmigan, Rock, 113 Willow, 113

Pteridium aquilinum, 235

Pueraria lobata, 31,307 montana, 31

Pueraria montana, Adventive in Southern Ontario, Kudzu Vine, 31

Puffin, Atlantic, 50

Puffin, Fratercula arctica naumanni, in Canada, A Specimen of the High Arctic Subspecies of Atlantic, 50

Puma concolor, 236,320,324,333 concolor couguar, 322

Puma concolor) in Manitoba, Canada, First Record of Parasites from Cougars, 324

Puma concolor, in Ontario: Additional Evidence, Cougars, 320

Puma concolor) Kittens with Live Prey: Implications for Learning and Survival, Observations of Wild Cougar, 333
Quebec, The Impact of Deer Herbivory and Drought on Population Growth of Goodyera pubescens (Orchidaceae) in Southwestern, 242

Quercus sp., 28 macrocarpa, 282

rubra, 32,160

Quigley, H., 333

Quillwort, Britton's, 255 Dodge's, 253

Quintana, N.T., 15

Rabbitbrush, Rubber, 34

Rabdophaga sp., 189 rosaria, 189 salicisrhodoides, 190 strobiloides, 189

Raccoon, 93,286

Racer, Eastern Yellow-bellied, 195

Rangifer tarandus, 192,217

Rangifer tarandus, in Northwestern Alaska, Sea Ice Crossing by Migrating Caribou, 217

Raspberry, 282

Rattlesnake, Prairie, 195

Raven, Common, 113,235

Rea, R.V. The Influence of Willow Salix sp. Rose Insect Galls on Moose Alces alces Winter Browsing, 189

Reddoch, A.H., 242

Reddoch J.M. and A.H. Reddoch. The Impact of Deer Herbivory and Drought on Population Growth of Goodyera pubescens (Orchidaceae) in Southwestern Quebec, 242

Redhead, 16

Redpoll, Arctic, 113

Reedgrass, Bluejoint, 1 Purple, 298

Reindeer, 192,220

Reithrodontomys megalotis, 95 megalotis dychei, 95 megalotis megalotis, 95

Reithrodontomys megalotis, An Addition to the Mammalian Fauna of Saskatchewan: The Western Harvest Mouse, 95

Rhododendron groenlandicum, 24

Rhus typhina, 32

Rhytidiadelphus triquetrus, 329

Ribbonsnake, Eastern, 231 Northern, 232

Ribbonsnake, Thamnophis sauritus, in Nova Scotia, Canada, A Significant Range Extension for the Eastern, 231

Ribes missouriense, 282

Richter, D.L., A.M. Berns, and C.F. Frederick. Resistance of Canada Yew (Taxus canadensis) Branch Wood to Two Wood Decay Fungi, 160

Roberts, N.M., S.M. Crimmins, D.A. Hamilton, and E. Gallagher. Implantation and Parturition Dates of North American River Otters, Lontra canadensis, in Southern Missouri, 28

Robin, American, 60

Robinia pseudo-acacia, 32

Roias, S.M., 210 
Rosa sp., 189

acicularis, 136, 299

gymnocarpa, 136

nutkana, 136

woodsii, 136

Rose, Wild, 136,298

Rose Insect Galls on Moose Alces alces Winter Browsing, The Influence of Willow Salix sp.

Ross, M.A., 204

Ross, R.K., 20

Rubus sp., 282

Rust, Soybean, 33

Salix sp., 24,136,189,296 scouleriana, 190

Salix sp. Rose Insect Galls on Moose Alces alces Winter Browsing, The Influence of Willow, 189

Sandpiper, Baird's, 111

Buff-breasted, 111

Pectoral, 113

Semipalmated, 113

Stilt, 111

White-rumped, 113

Sapsucker, 143

Sarcocystis sp., 288

Saskatchewan During a Drought Period, Distribution and Relative Abundance of Richardson's Ground Squirrels, Urocitellus richardsonii, According to Soil Zones and Vegetation Height in, 103

Saskatchewan, High Spring Mortality of Adult Richardson's Ground Squirrels, Urocitellus richardsonii, Associated with a Severe Rainstorm in Southwestern, 148

Saskatchewan, Observations of Nocturnal Hunting Behaviour of American Badgers, Taxidea taxus, in Southwestern, 226

Saskatchewan, Proximity to Hibernacula and Road Type Influence Potential Road Mortality of Snakes in Southwestern, 194

Saskatchewan: The Western Harvest Mouse, Reithrodontomys megalotis, An Addition to the Mammalian Fauna of, 95

Saskatoon, 136,303

Scaup, Greater, 15,113

Lesser, 16

Scaup, Aythya marila, Nest Site Characteristics on Grassy Island, New Brunswick, Greater, 15

Scirpus sp., 25

Scoter, 20

Black, 20

Surf, 20

White-winged, 20

Scoters (Melanitta spp.) in Ontario's Hudson Bay Lowlands, Abundance and Habitat Selection of Breeding, 20

Sculpin, Slimy, 207

Sealy, S.G. and H.R. Carter. Body Condition and Survival of Vagrant Long-billed Murrelets, Brachyramphus perdix, in North America, 6

Seburn, D., Review by, 175

Sedge, 15,25,62

Thick-headed, 62

Serfass, T.L., 281

Serrivomer sp., 211 jesperseni, 210

Serviceberry, Downy, 282

Setophaga occidentalis, 143

townsendi, 143

Shad, Gizzard, 10

Shepherdia canadensis, 299

Shiner, Emerald, 10

Shrew, American Pygmy, 2

Arctic, 1

Cinereus, 2

Maritime, 1

Northern Short-tailed, 2,38,93

Smoky, 2

Shrew (Sorex maritimensis) in Black Spruce (Picea mariana) Forest Stands in Southeastern New Brunswick, Occurrence of the Maritime, 1

Sialia currucoides, 113

mexicana, 41

Sicyos angulatus, 32

Sinapis alba, 226

Skunk, Striped, 150,283

Smith, T., Review by, 348

Smith, W.A., 15

Snake, 194

Northern Ring-necked, 336

Western Hog-nosed, 195

Snake, Diadophis punctatus edwardsii, from Big Tancook Island, Mahone Bay, Lunenburg County, Nova Scotia, Canada, A Partial Albino Hatchling Northern Ringnecked, 336

Snakes in Southwestern, Proximity to Hibernacula and Road Type Influence Potential Road Mortality of, 194

Snowberry, Common, 136

Somateria mollissima, 113 spectabilis, 111

Somers, C.M., 194

Soper, 1916-2012, A Tribute to James Herbert, 61

Sorex arcticus, 1

cinereus, 2

fumeus, 2

hoyi, 2

maritimensis, 1

Sorex maritimensis) in Black Spruce (Picea mariana) Forest Stands in Southeastern New Brunswick, Occurrence of the Maritime Shrew, 1

Soybean, 33

Sparrow, House, 38

Savannah, 59,113

White-crowned, 59

Spermophilus sp., 47,148

beldingi, 148

columbianus, 148

richardsonii, 103,148

Sphyrapicus sp., 143

Spruce, 47,296

Black, 1,24,295

Western White, 296,298

White, 234

Spruce (Picea mariana) Forest Stands in Southeastern New Brunswick, Occurrence of the Maritime Shrew (Sorex maritimensis) in Black, 1

Squirrel, Belding's Ground, 148 
Columbian Ground, 148,226

Ground, 47,226

Red, 93

Richardson's Ground, 95,103,148,221,226

Squirrels, Urocitellus richardsonii, According to Soil Zones and Vegetation Height in Saskatchewan During a Drought Period, Distribution and Relative Abundance of Richardson's Ground, 103

Squirrels, Urocitellus richardsonii, Associated with a Severe Rainstorm in Southwestern Saskatchewan, High Spring Mortality of Adult Richardson's Ground, 148

Stanton-Kennedy, T., Reviews by, 81,350

Stercorarius longicaudus, 113 parasiticus, 113 pomarinus, 113

Sterna hirundo, 15 paradisaea, 113

Strong, W.L. and T.S. Jung. Stand-level Attributes of Snowshoe Hare (Lepus americanus) Habitat in a Post-Fire Trembling Aspen (Populus tremuloides) Chronosequence in Central Yukon, 295

Sturgeon, Lake, 204

Sturnella magna, 143 neglecta, 143

Sumac, Staghorn, 32

Suricata suricatta, 333

Swallow, Barn, 143

Swan, Tundra, 113

Symphoricarpos albus, 136

Synaphobranchus affinis, 210

Tadarida sp., 38

Taenia omissa, 325 rileyi, 325

Tamarack, 1,24

Tamiasciurus hudsonicus, 93

Tanner, A.W., 231

Taxidea taxus, 47,95,221,226,234

Taxidea taxus, in Southwestern Saskatchewan, Observations of Nocturnal Hunting Behaviour of American Badgers, 226

Taxidea taxus, Use of a Dorsal Radio-Transmitter Implant in American Badgers, 221

Taxus baccata, 160 brevifolia, 160 canadensis, 160

Taxus canadensis) Branch Wood to Two Wood Decay Fungi, Resistance of Canada Yew, 160

Taylor, B.R., Review by, 75

Tea, Common Labrador, 24

Tenebrionidae, sp., 121

Tern, Arctic, 113 Common, 15

Tetrao tetrix, 331 urogallus, 331

Thalassenchelys coheni, 210

Thamnophis elegans, 199 elegans vagrans, 195 radix 195

sauritus, 231

sauritus septentrionalis, 232
Thamnophis sauritus, in Nova Scotia, Canada, A Significant Range Extension for the Eastern Ribbonsnake, 231

Thomas, H.H., P.R. Moosman, Jr., J.P. Veilleux, and J. Holt. Foods of Bats (Family Vespertilionidae) at Five Locations in New Hampshire and Massachusetts, 117

Thomomys bottae, 167 talpoides, 96

Thuidium delicatulum, 330

Thuja occidentalis, 160

Titmouse, Black-crested, 143 Tufted, 143

Toxocara canis, 288 cati, 325

Trametes versicolor, 161

Tree, Cabbage, 157

Tree-of-heaven, 32

Trefry, H.E. and G.L. Holroyd. An Extra-Limital Population of Black-tailed Prairie Dogs, Cynomys ludovicianus, in Central Alberta, 46

Triska, M.D., 281

Triticum aestivum, 221,226

Tryngites subruficollis, 111

Turdus migratorius, 60

Turnstone, Ruddy, 113

Turtle, Blanding's, 89,232

Turtles, Emydoidea blandingii, in Barren Meadow and Keddy Brooks, Nova Scotia, Ecology of a Recently Discovered Population Segment of Blanding's, 89

Twinflower, 298

Tyto alba, 38

Tyto alba) Predation on Big Brown Bats (Eptesicus fuscus) in Pennsylvania, Barn Owl, 38

Ulmus sp., 47 americana, 282

Uria lomvia, 50

Urocitellus sp., 226 beldingi, 148

columbianus, 148,226

richardsonii, 95,103,148,221,226

Urocitellus richardsonii, According to Soil Zones and Vegetation Height in Saskatchewan During a Drought Period, Distribution and Relative Abundance of Richardson's Ground Squirrels, 103

Urocitellus richardsonii, Associated with a Severe Rainstorm in Southwestern Saskatchewan, High Spring Mortality of Adult Richardson's Ground Squirrels, 148

Ursus americanus, 224,321 arctos, 224

Vaccinium vitis-idaea, 299

Vanderwolf, K.J., D.F. McAlpine, G.J. Forbes, and D. Malloch. Bat Populations and Cave Microclimate Prior to and at the Outbreak of White-Nose Syndrome in New Brunswick, 125

Veilleux, J.P., 117

Venefica sp., 210

ocella, 210

procera, 210

tentaculata, 210 
Venefica ocella and $V$. tentaculata (Nettastomatidae) from British Columbia, First Specimens of the Marine Eels, 210

Venefica tentaculata (Nettastomatidae) from British Columbia, First Specimens of the Marine Eels Venefica ocel$l a$ and, 210

Veratrum californicum, 55 viride, 55

Vermivora chrysoptera, 143 cyanoptera, 143

Viburnum edule, 303

Vine, Kudzu, 31

Vine, Pueraria montana, Adventive in Southern Ontario, Kudzu, 31

Vink, J.A.J., 111

Vitis riparia, 32

Vole, Meadow, 38 Southern Red-backed, 2

Vulpes lagopus, 114 macrotis, 224 vulpes, 95,235,288,321

Vulpes vulpes) and Coyotes (Canis latrans) on Prince Edward Island, Canada, Population Structure of Harvested Red Foxes, 288

Waldron, G.E. and B.M.H. Larson. Kudzu Vine, Pueraria montana, Adventive in Southern Ontario, 31

Walker, D., 306

Walker, T.S., 204

Wapenaar, W., F. de Bie, D. Johnston, R.M. Oahandley, and H.W. Barkema. Population Structure of Harvested Red Foxes (Vulpes vulpes) and Coyotes (Canis latrans) on Prince Edward Island, Canada, 288

Warbler, Blue-winged, 143

Golden-winged, 143

Hermit, 143

Townsend's, 143

Watkins, W.G., 324

Weasel, Long-tailed, 95,228,234

Weis, L., 320

Werner, J.R. Vancouver Island Marmots (Marmota vancouverensis) Consume Plants Containing Toxic Secondary Compounds, 55

Wheat, 221,226

Wheatear, Northern, 59
Wheatgrass, Crested, 104,148,221,226

Slender, 104,148,221,226

White, B.N., 320

White-Nose Syndrome in New Brunswick, Bat Populations and Cave Microclimate Prior to and at the Outbreak of, 125

Wick, A.A., J. Janelle, S. Pruss, and N. Erbilgin. First Observations of Mormon Metalmark (Apodemia mormo) Oviposition Behaviour in Canada, 34

Wicopy, 86

Willow, 24,136,189,282,296 Scouler's, 190

Willow Salix sp. Rose Insect Galls on Moose Alces alces Winter Browsing, The Influence of, 189

Wolf, 237

Eastern, 235

Gray, 238,324

Red, 143

Wolf (Canis lupus), Severe Maxillary Osteomyelitis in a Gray, 238

Wolverine, 234

Wood, Lead, 87

Woodchuck, 56

Woodfern, 253

Algonquin, 253

Fragrant, 253

Woodrat, Bushy-tailed, 96

Woodsia sp., 253

Xema sabini, 113

Xenomystax atrarius, 210

Yew, Canada, 160

English, 160

Pacific, 160

Yew (Taxus canadensis) Branch Wood to Two Wood Decay Fungi, Resistance of Canada, 160

Youngman: 1927-2011, A Tribute to Phillip Merrill, 167

Yukon, Stand-level Attributes of Snowshoe Hare (Lepus americanus) Habitat in a Post-Fire Trembling Aspen (Populus tremuloides) Chronosequence in Central, 295

Zonotrichia leucophrys, 59 leucophrys leucophrys, 60 


\section{Index to Book Reviews}

\section{Botany}

Iason, G., M. Dicke, and S. Hartley. The Ecology of Plant Secondary Metabolites: From Genes to Global Processes, 178

Wenxin, C. and W. Entao. Rhizobia in China, 347

\section{Environment}

Bennet-McCuaig, C. Encountering the Wild, 77

Black, B.C. and G.J. Weisel. Global Warming. Historical Guides to Controversial Issues in America, 77

Bodin, Ö. and C. Prell. Social Networks and Natural Resource Management: Uncovering the Social Fabric of Environmental Governance, 81

Galatowitsch, S.M. Ecological Restoration, 75

Hallett, S. with J. Wright. Life Without Oil: Why We Must Shift To a New Energy Future, 80

McAlpine, D.F. and I.M. Smith. Assessment of species diversity in the Atlantic Maritime Ecozone, 71

Townsend, D.W. Oceanography and Marine Biology: An Introduction to Marine Science, 81

\section{Other}

Gepts, P., T.R. Famula, R.L. Bettinger, S.B. Brush, A.B. Damania, P.E. McGuire and C.O. Qualset. Biodiversity in Agriculture: Domestication, Evolution and Sustainability, 348

Gotelli, N.J. and A.M. Ellison. A Primer of Ecological Statistics, Second Edition, 350

Kålås, J.A., Å. Viken, S. Henriksen, and S. Skjelseth. The 2010 Norwegian Red List for Species, 349

Norment, C. In the Memory of the Map: A Cartographic Memoir, 179

Roed, M.A. and R.J. Fulton. Okanagan Geology South: Geologic Highlights of the South Okanagan Valley, British Columbia, 263

\section{Zoology}

Adler, K. Contributions to the History of Herpetology. Volume 3, 344

Ayé, R., M. Schweizer and T. Roth. Birds of Central Asia: Kazakhstan, Turkmenistan, Uzbekistan, Kyrgyzstan, Tajikistan, Afghanistan, 260
Burton, R. and J. Croxall. A Field Guide to the Wildlife of South Georgia, 176

Crother, B.I. Scientific and Standard English Names of Amphibians and Reptiles of North America North of Mexico, with Comments Regarding Confidence in Our Understanding - Seventh Edition, 340

de Boer, B., E. Newton and R. Restall. Birds of Aruba, Curacao and Bonaire, 70

Ernst, C. and E. Ernst. Venomous Reptiles of the United States, Canada, and Northern Mexico. Volume 1, 175

Forsman E. and 26 co-authors. Population Demography of Northern Spotted Owls, 174

Grimmett, R., C. Inskipp, and T. Inskipp. A Guide to the Birds of India, Pakistan, Nepal, Bangladesh, Bhutan, Sri Lanka, and the Maldives, 71

Heatwole, H. and J.W. Wilkinson. Amphibian Biology Volume 10. Conservation and Decline of Amphibians: Ecological Aspects. Effect of Humans, and Management, 341

Holman, J.A. The Amphibians and Reptiles of Michigan: A Quaternary and Recent Faunal Adventure, 342

Kennedy, A. Birds of the Masai Mara, 261

Kennedy, A. and V. Animals of the Masai Mara, 261

Lovitch, D. How to be a Better Birder, 68

McLaren, I. All the Birds of Nova Scotia, 172

Meshaka, W.E. Jr., and J.T. Collins. A Pocket Guide to Lizards and Turtles of Pennsylvania, 345

Mikkola, H. Owls of the World: A Photographic Guide, 346

Nicholas, E., E. Mandrak, and M. Burridge. The ROM Field Guide to Freshwater Fishes of Ontario, 173

Spotte, S. Societies of Wolves and Free-ranging Dogs, 177

Thorington, R.W., J.L. Koprowski, M.A. Steele and J.F. Whatton. Squirrels of the World, 262

Tozer, R. Birds of Algonquin Park, 69

\section{Children's Books}

Patkau, K. Ecosystem Series: Who Needs a Swamp?, Who Needs a Jungle?, and Who Needs an Iceberg?, 83

Urrutia, M.C. Who Will Save my Planet?, 83 